\title{
Sven Nilsson and the Invention of Modern Man
}

\author{
Johan Hegardt
}

\begin{abstract}
During the early 18th century archaeology was both materialistic and idealistic. Since the end of the century idealism has been excluded. Processual archaeology was, for example, highly materialistic. In this article an idealistic principle is reintroduced, though in a different form. Idealism is instead understood as an ethic.
\end{abstract}

Johan Hegardt, Department of Archaeology, Uppsala University, S-753 10 Uppsala, Sweden.

Sven Nilsson (1787-1883) was active as a zoologist, geologist and archaeologist during a time of significant scientific change. However, this article will not deal with his colossal scientific production. Instead I will discuss his idealistic and materialistic point of departure and the theoretical aspects of early 19 th-century archaeology. I will also to a certain extent relate this discussion to processual archaeology and post-processual archaeology.

Post-processualism and post-structuralism have criticised structuralism and positivism, two theories of science that have dominated modern thought since the 19 th century. It is difficult to identify modernism, but Michel Foucault has seen the beginning of modernism in Kant's short article Beantwortung der Frage: Was ist Aufklärung?

For Foucault Kant's text was an attempt to identify a philosophical starting-point, and he criticised the actuality of philosophical discourse. By making the relationship between the practiser and the practice a problem, Kant concentrated on philosophy in itself and tried to identify a philosophical "We" - we the philosophers. After this it has not been possible to neglect one's own iden- tity and possessions, a fundamental principle in the discourse of modernity (Foucsur: 1992:42) and of evolutionary theory.

By this example Foucault also emphasised that modern man is an invention, or more clearly, a conception. For Foucault, the French palaeontologist Georges Cuvier (1769-1832) was one of the inventors. Sven Nilsson considered Cuvier as the "high priest" of natural science (Nilsson 1875b:45) and he was influenced by Cuvier in his scientific thinking. Therefore we can also view Nilsson as one of the founders of modern archaeology, an opinion early expressed by E B Tylor (Tylor 1871:55p). Nilsson also contributed to geology and zoology and therefore to modern evolutionary theory. This is significant, because it is in this context that modern archaeology is shaped. Consequently this archaeology has many similarities with processual archaeology, criticised by post-processual (post-modern) archaeology.

Sven Nilsson was aware that his thoughts were new and of considerable importance. His archaeology was also appreciated, and critics pointed out that he had questioned traditional, national and speculative classical 
thoughts.

It was, Nilsson stressed, necessary to join many different sciences if the discourse of modern archaeology should be developed (Nilsson 1866:VI). But Nilsson's scientific thinking is not understandable without taking into account his religious views. Nilsson was a believer. His religiousness could be described as pantheism (Regnéll 1983b) and the significance of his evolutionary system should be understood against this background. Evolutionary theory does not make sense without the religious aspect. Processual archaeology has therefore excluded one of the fundamental principles of evolutionary theory. Instead the materialistic aspects of evolution have been emphasised. The background is found in the late 19th-century critique against idealism and metaphysics. But this does not mean that processual theory has eliminated the metaphysical problem. Evolutionary theory always builds on a metaphysical principle, explicit in early and mid19th century archaeology and implicit in the 20 th century. This is one of many paradoxes in modern thought.

\section{ZOOGEOGRAPHY}

In 1816 Nilsson travelled to Norway to study aquatic birds. Birds, he concluded, like plants and mammals, could be divided into geographical zones. This was new, because at the time collecting and describing different species was the course of science. Ecological conditions and modes of living were of subordinate significance.

Ten years later Nilsson stressed that during this trip he had tried to fix the regions of the Scandinavian fauna. A region could be described as the contextual condition for a species. Each species had its special position inside this organic and geological context. The context was interpreted as a timeless and fixed system - the modern metaphysics of presence. Nilsson adjusted the rigid taxonomical principles of the 18th century, the Linnean principle of classification, to a holis- tic system where every species has its fixed position inside this system - the modern metaphysics of totality. The idea of fixed systems raises the question of change and development, the main topic of all evolutionary theory - the modern metaphysics of time.

Taxonomy built on the idea that the source material should be ordered after morphological attributes. The concept of taxonomy has its origin in the Greek word taxis, which means arranging, and the word nom'os, which means law. Taxonomy therefore falls back on the principle of arranging nature after its laws. Anatomy made these taxonomic systems more and more complicated and it was with Cuvier that the classical taxonomical systems were invalidated. For Cuvier it was the functional aspects that were the aim of classifications, not order in itself but life itself and the features concealed behind the visible. There was no longer a need for a general taxonomy. Instead it was the difference between organic features that was the aim of science. A hierarchy of significance was created whereby the visible parts of the organism were of subordinate meaning. It was instead those parts that had to be made visible through dissection that were of basic scientific significance. On a deeper level there existed another pair of opposites. This was the opposition between organs that were common, spatially situated, solid, directly or indirectly visible and those organs that were not visible but had a determinant function, that is, the aspects that order what we can observe. A third opposition also existed, that between what identifies and what separats. This way of reasoning changed the scientific thinking from a taxonomic view of life to a synthetic. In Foucault's opinion this was also the first step toward a modern biology (Foucault 1991:268p). This is of some importance. Life is of essential meaning in this article and we shall later see how this view of life can be criticised. 


\section{INAUGURAL LECTURE}

In his inaugural lecture (1832) Nilsson emphasised that every class in zoology must include its own history. Nilsson also noted that the animal species were already ordered in the Bible. Solomon's classification into mammals, birds and reptiles could still be used (Nilsson 1875a:1pp). Nilsson's famous work Skandinavisk fauna (1835) was, in fact, divided into four parts: Birds, Mammals, Fish and Amphibians. In this work Nilsson explicitly breaks with the old Linnaean system of classification and implies a holistic thinking in which we find geological, geographical and economical aspects (Löwegren 1983:134).

The zoology of Aristotle was for Nilsson a comprehensive source of comparative and empirical experience (Nilsson 1875a:10). The method of Aristotle was in Nilsson's opinion anatomical, physiological, psychological, and from beginning to end comparative (Nilsson 1875a:4p). It was in this context that Nilsson placed Cuvier (Nilsson 1875a:6).

Cuvier's comparative anatomy made it possible to formulate two distinct continuities in the world of the living. The first is the function of the species. Thereby the organic world was ordered after complexity, from the simplest organism to mankind. The second is the complexity of the organs. These two aspects helped Nilsson when he ordered the cultures hierarchically, after social and technical complexity, whereby the function was similar to the social or cultural level and the complexity of the organs was similar to different technical levels.

During the classical period it was the differences that made it possible to order the species. With Cuvier the differences are isolated in themselves, and the discontinuities or the lack of cohesion are justified by each organism's special being. The ontology of the classical period is therefore changed with Cuvier. There is no longer a question of a web of differences. Instead all living beings are isolated in contexts completely detached from one another. It is the contexts that are crucial for the maintenance of life. The different forms of biological being are part of a regional and autonomous life (Foucault 1991:272p). It was this that Nilsson understood during his Norwegian trip.

For Nilsson, all animals had a soul and were living and feeling creatures and should not be studied as dead things (Nilsson 1875a:7). It is therefore necessary, Nilsson stressed, that manner of living and modes of production, mental quality, customs, creative powers, calculation and guile, native devoutness and hatred against each other in the world of animals should be investigated (Nilsson 1875a:6). All this had been neglected in the old taxonomic schemes. This was Nilsson's method of comparative psychology but also his pantheism. If God animates all living beings, the products of life or life itself can not be viewed as dead things. Instead all living beings are animated by God's purity and wisdom. It was God's creative powers that ordered the world of the living. Therefore scientific truth was not a question of political (ideological) or religious speculations.

In Cuvier's thinking, life was also of central significance. The discontinuity between different conditions of life was explained by differences in requirements. Thereby a relationship between the organism and the external foundations for life had been established. Life could no longer be understood as an isolated feature. Instead the organic structures established a functional relationship with an external world (Foucault 1991:273). By this organic functionalism, Nilsson could claim that the Stone Age people produced their tools and weapons by instinct in relation to external conditions. The technological standard could therefore be used to evaluate the degree of adaptation to external conditions. It is also this way of reasoning that has guided the functionalist theories of processualism (Hodder 1982a:2p; Tilley 1989: 
$187 \mathrm{p})$.

After Cuvier every living creature has been bound to its own being, and it is no longer a question of placing the living in taxonomical systems. Instead the living exist in a dual space that consists of an internal anatomical and psychological space as well as an external space that makes this life possible. But they were both subordinated a common control - the Plan, the fundamental principle for every form of life (Foucault 1991:274).

Sven Nilsson contributed to the modernisation of science. This does not mean that there was a diffuse change or adaptation to some vague contemporary thought. The idea of modernism was far more complicated. Modernisation of thought is the critical relationship to contemporary time and also the problem of naming this contemporary time. Modernism was the name given to a special way of reasoning. During the first half of the 19th century modernism consisted of both idealism, that is the plan of God, and materialism, that is the empirical and technical world. During the later part of the century idealism was excluded.

\section{GEOLOGY}

Geology and ethnography - younger subject fields of science - were considered speculative by conservative scientists. They also criticised these sciences for turning away from basic classical research programs. That classical thoughts were considered proper science, emphasises the conflict that modernism involved.

Foucault continually points out the difference between Cuvier's thinking and a classical way of reasoning. This distinction is also stressed by Nilsson (Nilsson 1875a:6, 1875b:48p). During the classical era the taxonomical systems were based on morphology, numbering, arrangement, size and so on. All these aspects could be controlled by the eye and by language. The taxonomical systems of the 17 th and 18 th centuries were a question of linguistic principles, that is, giving names with general significance. During the 19th century anatomical differences should be exposed and functional systems isolated. The anatomical dissection made it possible to formulate more complicated family systems (Foucault 1991:269). It is again this way of reasoning that guided Nilsson when he ordered the evolution of cultures. By psychological and anatomical comparison - functional and technical levels he tried to identify the differences between the separate stages.

Nilsson also underlined that geology contributed to archaeology (Nilsson 1838-43:I). The main task of geology was to show the facts behind geological transformations. But it was also, Nilsson stressed, important to note that the transformations did occur very slowly. Geology could not produce absolute dates, but only point out the changes that occurred first and what followed. Geology could therefore only present relative dates. Nilsson was here inspired by the French geologists Cuvier and Alexander Brongniart and their method of dating geological phenomena (Regnéll 1983a:38p). Nilsson also used Lyell's principle of actuality (Frängsmyr 1976:15).

In Nilsson's system the species took shape, developed and disappeared within a geological context. The species were therefore dependent on the surrounding environment. When changes in the environment occurred, the species disappeared. Geology, Nilsson said, teaches us that the organic world slowly develops from one stage to another. Nature's firstborn species was the most primitive and was replaced by more and more "educated" up to the last, most perfect organisms (Nilsson 1838-43:I). This might give the impression that Nilsson's evolutionary theory was grounded in two contradicting statements, one emphasising a fixed system and the other stressing a slow flowing change. But this is not the case. Instead they are dependant on each other. It is a paradox that 
shapes the synthetic understanding of life and evolution.

In Foucault's opinion, it was Cuvier who formulated the foundation for a future evolutionism. By introducing a radical principle of discontinuity he created the basis for biological distinctions, external necessities and the conditions for life. He also stressed that life had to be maintained through some kind of energy. He therefore concluded that life was under a constant threat. Nilsson was of the same opinion. This made it possible to shift from a naturalhistory to a history of nature. A similar shift is noticeable in archaeology. During the beginning of the 19th century there was a change from antiquarianism to archaeology.

The break with the classical theories of evolution made it possible to formulate a historicity latent in the existential principles of life. Cuvier's attempt to analyse the principles of life was the first effort in Western science to formulate the foundations for this historicity (Foucault 1991:275). It is this historicity that Nilsson uses when he analyses the cultural evolution. He thus shifts the discourse from the taxonomical principles of antiquarianism to an archaeology of life. The ancient finds are no longer dead things but a part of life, they are artefacts.

History is now connected with life and it is life that shapes evolutionism. But in the days of Cuvier there did not exist a history of the living similar to a future evolutionism. It was, however, Cuvier who gave each species a history by fixing the conditions of life: life was historical. Cuvier did therefore not oppose history by fixing the conditions for life. Instead he criticised the chronological thinking of the 18th century. Cuvier's fixed systems can therefore only be understood in relation to history (Foucault 1991:276), a paradox similar to Nilsson's thinking.

By giving life a history, it became possible for the modern thinking to grasp life as a quality in itself. During the 18th century chronology was only a curiosity, a more or less confused expression of the different orders of being. By the 19th century chronology expressed instead more or less explicitly the historical conditions of mankind and objects (Foucault 1991:276). This was only possible if life and history were a part of a plan, the spirit of God.

In Nilsson's opinion, the course of nature could be connected with the evolution of human culture. He underlined this analogy by pointing out that nature and the evolution of culture was a question of laws. But Nilsson never explained the powers behind evolution. Instead he meant that this force was immanent in nature, a law that one could not find - the secret of God. The scientist could only describe and explain the empirical processes of nature and human culture, that is, the materialistic aspects of evolution.

That this was the case is strengthened by the fact that Nilsson's idea of evolution was closely connected with Cuvier's zoological systems and the fact that Cuvier was convinced of the divine nature of organic life. But this does not mean that Nilsson and Cuvier wanted to justify biblical speculations by scientific analyses. On the contrary. But Nilsson and Cuvier could not avoid viewing nature as a system leavened by divine mystique, that is, the idealistic aspects of evolution.

Cuvier used comparative anatomy as a zoological and palaeontological tool. Organic facts were given meaning in relation to function. Function was the main principle when ordering living organisms. Cuvier structured the organic world by freeing the organic aspects from the taxonomical principles. The structures became the foundation for all forms of internal relations. Function was the core of the analyses. By giving function a superior position, everything that had earlier been in reach through experience was now given a new meaning. It was a question of bringing together facts that did not have any external features in common. Instead it was function that should be the central and 
basic variable.

This gave birth to new relationships. Different aspects could now depend on each other. Internal hierarchies were shaped that expressed differences in meaning and different organic functions were separated from each other and viewed as independent. This also indicated that there existed a plan behind the visible, a plan that regulated and controlled the vital functions. The essential functions were also given a superior position in this plan, and a principle of hierarchy had been formed. By this theory of function, species could resemble each other but at the same time be separate from each other. What eventually bound them together was more a question of invisible identities that were related to different levels of function, not to similarities (Foucault 1991:263ff).

I shall later return to Hegel. Here I would like to point out Hegel's understanding of the God-idea. If God was placed outside reason there was no need to worry about the nature of God, and the causes of history would not be connected with reason. Instead reason and the divine should be related, and true humility was recognizing God in everything, even in the reasonable course of history. The course of history was spiritual and it was possible to understand God through the course of history. God was analogous with truth. The Christian is initiated in the mystery of God and has the key to history. The Christian understands Providence and its plan. History was for Hegel the evolution of God in a fixed element. No other fixed knowledge was possible. Knowledge was the realisation that the eternal wisdom had appeared on the spiritual scene as well as on the scene of nature. Therefore Hegel's history was a theodicy (Hegel 1986:34ff).

The idea of a plan was consequently a prerequisite for both natural science and the philosophy of history. Nilsson never explained Providence as well as Hegel did. But he did, as did Hegel, try to give God and Providence a position in the laws and the processes of nature, history and the evolution of man and his culture. This was Nilsson's pantheism, his idealistic understanding of the material world. Nilsson also stressed the superior position of modern man over both nature and primitive man. Reason, freedom, morality and conscience gave evidence of the immortality of the soul (Nilsson 1875b:52). This meant that a scientist who studied the wonders of the Creation must also raise his thoughts to the sublime wonders of God. This kind of science could never lead to materialism (Nilsson 1875b:52). On the contrary, the purpose of science was to protect the soul from the danger of death, the primitive chaotic forms of being and the insecurity of the future. The modern conception of Science, the science of Sven Nilsson and his later followers builds on the metaphysics of the presence, in which life and death are excluded by a curtain of truth and reason. It is the principle of defining the presence, a timeless definition of "We" - we the scientists, we the gods of truth - that leads to the narcissism and arrogance of modern thought which is expressed in the materialistic thinking of processual archaeology and which was sanctioned by early 19th century idealism. Life and death could therefore be a part of history but not a part of contemporary science. The scientist and the society that the scientists were shaping were excluded from the course of history. Modernism has therefore always been a question of ending the course of history, of creating a lifeless totality with no future and no past, that is, the transparent reality of the presence.

\section{EVOLUTION AND REVOLUTION}

For Nilsson the detail only had meaning inside a systematic whole. But systematisation was not sterile and dead, it was not only materialism. Instead it was grounded in the living, in life itself. Nilsson worked hard for the logical and empirical principles of modern science. He wanted to see a resemblance between the method of natural science and 
philology and geometry (Nilsson 1875b:40). But he also criticised conservative critics who connected progressive movements of modern science with the revolutions that had swept through Europe (Nilsson 1875b:47). This was not the case, Nilsson stressed, because the scientist only came in contact with a smoothly advancing progress. This in turn influenced his mind. Therefore a scientist could be neither conservative nor revolutionary. Instead Nilsson pleaded for the smooth and secure progression of science in line with nature (Nilsson 1875b:48). Social evolution and the evolution of science could be understood as a natural progression. This does not mean that Nilsson neglected the problem of change. On the contrary, evolution demanded that the obsolete - the obsolete text of science and culture - must be invalidated, not by revolutions but through the immanent logic of nature and the plan of God. A similar view was later expressed by Binford: "We feel that archeology in the 1960's is at a major point of evolutionary change. Evolution always builds on what went before but it always involves basic structural changes" (Binford 1968:27).

But this should not be confused with the idea that there is a future and that the scientist is part of the historical process he tries to describe. On the contrary, every time we meet this kind of statement it expresses the idea that science has fulfilled its commitment and that it is now only a question of detail before the system of totality is complete. The scientist has instead placed himself outside the course of history - life and death - where he, separated from the world he analyses, can cultivate the myth of his own immortality. And when this "expert" speaks, the rest of the society follows. The scientist then creates an external social world, a world of which he is not a part. If this creation builds on a materialistic and evolutionary theory, the narcissism of contemporary society is understandable. It is this scientific meaning that has been criticised by post-processual arch- aeology. But this critique should not be confused with modern critique, that is, Kant's critique of the epistemological principles. Instead post-processual archaeology has tried to place science in a social context by pointing out the need for self-reflection, that is, viewing the scientist as part of the social world - life and death.

\section{MATERIALISM AND EVOLUTION}

For Nilsson it was the material conditions that expressed a culture's position on the evolutionary ladder (Nilsson 1835:XXI). This presupposed a special worldview. Nilsson also pointed out that there existed two major axioms. Firstly, human culture had evolved from the highest form of human purity and wisdom. Secondly, human culture had evolved from the lowest and most primitive level of brutality. In Nilsson's opinion, every culture had started its history from an uneducated and brutal position and slowly developed into a more civilised society (Nilsson 1835: XXII).

This way of reasoning made it possible to systematise the cultural evolution on empirical grounds. Nilsson worked systematically, empirically and theoretically and tried to develop a general evolutionary theory, a theory that should have the same relevance for the cultural evolution as for the evolution of nature.

He believed that the comparative method of natural sciences would make it possible to extend the investigations further back into history than the historical documents allowed. Through natural science an extinct animal world had been reconstructed by comparison with living organisms. It was Nilsson's idea that the same comparative method could be used to reconstruct the remains of ancient cultures (Nilsson 1843: $132,1875 \mathrm{c}: 70)$. Nilsson had used the method as a zoologist and was therefore well informed of its advantages (Nilsson 1875c: 70). The cultural evolution was with this point of departure analogous with the evolu- 
tion of species.

The first Scandinavian inhabitants must, by the logic and reason of evolution, have been hunter-gatherers. They produced weapons and tools by instinct. This was the only accurate explanation to the empirical facts, which indicated that everywhere primitive man appeared he was always connected with similar materials and technical standards (Nilsson $1875 \mathrm{c}: 85 \mathrm{p}$ ). In these conditions the trace of a higher wisdom was evident, a wisdom that gave all living species natural weapons but under such circumstances that, by the logic of evolution, they were step by step changed. It was, however, only man that could become more and more complete. Man could therefore get rid of his primitive weapons and tools and improve his technical standards by changing his cultural conditions (Nilsson 1875c:86p). When the comparative studies had been extended to every corner of the world, the complete answer to the question of cultural evolution would be given.

In Hegel's opinion, primitive man should not be viewed in line with Rousseau. In Hegel's evolutionary philosophy mankind moved to a higher and higher stage of freedom and reason. The American Indians were the primitive people from which this aspiration had started. Rousseau's statements were therefore from the Hegelian point of departure absurd. This also shows the significance in Nilsson's choice between the two axioms. He takes a considerable step when he chooses the second of the two.

In the beginning of the 19th century there was a shift from the naturalism of Rousseau to a conception of brutality. It was no longer a question of viewing these people as nobleminded. Instead they were seen as the primitive and brutal embryo of evolution. This was regarded as an objective reality. The different cultures were classified in a proper order of evolution, in line with the idea of science and reason. The societies of the world should be classified and evaluated by economical and technical standards, that is, according to their complexity.

The task for Nilsson was to formulate a reasonable explanation to his evolutionary scheme. This he found in nature. Nature showed that the first living organisms were the most incomplete. After these there followed more and more educated ones, up to the most complete. Every organism - even mankind - and the organic nature as a whole, therefore developed from the lowest natural stages to the highest order. Evolution was a question of nature's laws and logic (Nilsson 1838-43:I). By ordering the evolution of culture on these pre-conditions, sceptical arguments were eliminated. The idea was strengthened by the fact that the laws of nature and evolution were the plan of God.

The progressive process of evolution was, however, not only a material question. Nilsson's evolutionary principles also included the intellectual and spiritual evolution of mankind. The process was therefore a fundamental immaterial problem. But it was only the material coating that could be viewed by the scientist (Nilsson 1838-43:I).

Nilsson accordingly sees the material world as a reality and the successive development as a theoretical abstraction, a historical theory a priori. Life is therefore synthetical and the evolutionary process is consequently transcendental, a model or a way of explaining the course of history that exceeds the empirical reality. The different cultures appear as species which are dependent on the surrounding environment for their existence. It is the plan of Providence that is the motivating power behind both the geological and environmental aspects and the cultural historical processes. Therefore the different cultures as well as the different species are succeeded by higher and higher organic forms or by more and more educated and civilised cultures.

The course of evolution was predestined. If this process was to be studied the material world had to be separated from the spiritual. Nilsson's theory of evolution could therefore 
be viewed as two-sided. It was both material/ empirical and idealistic/metaphysical. By understanding evolution in this way, Nilsson could place cultures with a similar technology in the same context. Both the history of culture and the history of nature were based on a conception of a fixed and static condition for each epoch. Each species appeared only in its own, fixed, anatomical form. The primitive Stone Age man - the Savage - could therefore only be understood and analysed as such. But it was the idea of evolution, the theoretical and transcendental point of departure, that made it possible to explain the difference between epoches. This also gave the fixed material and empirical reality its dynamic significance. Binford's idea of statics and dynamics is not far away from this early 19 th-century metaphysics.

The purpose of Nilsson's system was to divide the cultural and intellectual evolution of mankind into different stages. The lowest stages were comparable, independent of their place in time or space. The tools had been manufactured by instinct and man had been close to a state of nature (Nilsson 1838-43:V; 1848:4). Therefore Nilsson expressed the opinion that the discourse of archaeology should build on comparative ethnography and natural sciences instead of historical sources and historical analogies. He transferred the theoretical and methodological aspects of natural sciences to a complex cultural evolutionary theory. Nilsson also explicitly expressed the opinion that this way of reasoning had been developed by Cuvier (Nilsson 1856:42). The method had been in use in all natural sciences and was therefore also suitable for archaeology (Nilsson 1848:3p). Nilsson's comparative ethnography, or comparative archaeology, should therefore be a part of the natural sciences and not a part of the historical sciences (Nilsson 1856:42).

Sven Nilsson's evolutionary scheme was at first divided into three stages: the Savage, the Nomad and the Peasant (1835). He later pointed out a fourth stage, - a society with a written language, mint-production and division of labour (Nilsson 1838-43:V). Mankind was now slowly moving closer to the highest level of culture with its elevated humanity (Nilsson 1838-43: Vpp), which is the conception of modern man. It is this conception that produces the idea of evolution. Evolutionary theory is therefore connected with the narcissism of modern logic and reason and the idea that contemporary time should be identified and named. The metaphysics of a presence and its totality gives birth to an idea of difference between cultures on a time-scale. Modernism is therefore based on three metaphysical fundaments: time, totality and presence.

The evolutionary perspective - in any form - always gives superiority to contemporary time. This is the logical consequence of evolutionary theory, a theory that would lose its significance without this narcissism. Since the formulation of the Three Age System and Nilsson's evolutionary scheme, archaeology has worked with evolutionary principles. Therefore history will always be ordered arbitrarily for the implicit or explicit purpose of emphasizing the actuality and superiority of one's own cultural and intellectual development. Evolutionism in any form is therefore always a question of the difference between the primitive and modern, the old and the new. But there has been a shift in the evaluation of the primitive, from a higher manner of living as for example in Rousseau's thinking, to a brutal manner of living - the modern idea of evolution. Today we sometimes find a relapse to the idea of a higher manner, expressed by some naive and romantic cultural critiques. During the 19th century the purpose of evolutionary thinking was to emphasise the moral, technical and intellectual superiority of modern time over other forms of social organisation. In functionalist and evolutionary theory of the 1960 s and 1970 s this opinion was not only implicit but immanent in the idea of logic and reason. 


\section{HEGEL}

Not only the Three Age System was created during the palmy days of Hegel. Also the evolutionary scheme of Nilsson could be placed in this context. But Hegel excluded pre-history from his historical thinking, because the light of his historical idea could not reach the dark prehistoric times. Instead he placed the beginning of history in China and India (Taylor 1986:493). The course of history had taken a route via Greece and Rome to the medieval and feudal Europe, where it reached its peak in the modern 19thcentury Europe.

Nilsson, however, thought he had the tool that was needed to open the sealed pre-history, the skeleton key that Hegel's historical theory did not obtain. Nilsson's tool was the comparative method of natural science. For Hegel reason was in line with the nature of the objects. He therefore meant that the modern enlightenment defined man as a thinking being and that reality was in line with this way of reasoning. This implied that modern science tried to understand the world as something conformable to law, in line with the nature of reason-Being (Taylor 1986:501).

Hegel's philosophy of history was a reaction against a speculative science of history. This was similar to the archaeology of Nilsson. In Hegel's opinion, history should be viewed empirically (Hegel 1986:24). But this was only one half of the historical investigation. The other included the question of the historical spirit (Hegel 1986:47). If speculations were excluded and the world was viewed as reasonable, the world would also stand out as reasonable. History should therefore be regarded with reason and causes and effects made intelligible (Hegel 1986:24, 26). History must then be viewed teleologically. The historical events - the empirical aspects - had been given meaning, a higher justification: the plan of God (Taylor 1986: 487). Reality was submited to reason and Hegel wanted to turn everything into history, even nature. The course of history was the aspiration of reason to a higher freedom, and therefore everything that happens must be significant and reasonable (Hegel 1986:17).

This means that every phenomenon must develop. The power behind this development was the contradiction between the external reality and the phenomenon that was developing. This contradiction dissolves every distinct form and gives birth to a new given form. The course of history is thereby following an essential dialectical plan (Taylor 1986: 489). Because reason is controlling reality, the course of history must consequently be reasonable (Hegel 1986:21). The fulfilment of the spirit demanded that a spirit of community be developed, a community that embodied and expressed reason. This fulfilment was the course of history (Taylor 1986:487).

But the dialectical aspects behind this course were beyond man's insight. Change occurred instead because of the cunning of reason (Hegel 1986:103; Taylor 1986:490f) that goes beyond the individual and fulfils the general significance of history. But it is not a question of a supraindividual subject that uses man for its purposes. On the contrary. Man is the bearer of the spirit. Even early man could feel the demand of the spirit, but then only by instinct. Hegel uses the word instinct to describe man's unconscious recognition of his meaning in the course of history (Hegel 1986:86; Taylor 1986:491). The spirit of the world - the cunning of reason - was therefore an immanent urge within mankind. This urge must be an instinct and therefore something that people could not understand completely (Taylor 1986:492).

The course of history should not be understood as a destiny but as a progress from the incomplete to the complete. The startingpoint for this process was the brutal stage of nature, and the goal was the perfection of reality and the implementation of the state. Hegel wanted to explain the being as a significant totality where everything had its fixed position inside the system. By this holistic principle of reason he concluded that his 
history was true a priori. This was also the course of evolution for Nilsson. The modern society is therefore an invention. It only exists through the idea of history, reason and logic. The modern idea of archaeology should be understood as part of this modern thought and does not and will not express any objective or true statements of any pre-modern society. Processual or any other kind of modern archaeology can only be understood as a discourse within the discourse of modernism. Modern archaeology has therefore since the beginning of the 19th century locked itself inside the discourse that defines it, and the statements of modern archaeology can not go beyond or transgress themselves. Modernism has by definition closed the door to the past.

\section{HEGEL IS CRITICISED, THE FIRST STEP TO MATERIALISM}

During the 1850s the Hegelian philosophy of history was criticised and considered speculative. Instead the science of history should be an independent empirical science. History should not be measured by non-historical scales but be based on empirical grounds. The principle was to describe the historical phenomena as objectively as possible. The historical science was understood as a cumulative process through which a more and more complete and total knowledge had evolved.

But Hegel and others, for example Nilsson, had never neglected historical facts. In their opinion it was instead a question of understanding history. This was not possible without a historical theory through which the historical facts could be interpreted. This was the crucial point in Hegel's logic. Hegel's theory was therefore a principle of interpretation for historical science and it was the historian's task to interpret and order the historical facts in relation to a determinant process of evolution. The critics neglected this. Instead they meant that the historian should uncover historical structures through empirical investigations (Lübcke 1987:19). History should be based on historical facts, that is, on positivist principles. In this context the interest in positivist philosophy and natural science increased. The science of history should become a natural science (Lübcke 1987:29).

The most powerful of the critical opinions was delivered by neo-Kantian historians. From this point of departure the Hegelian metaphysics stood out as highly speculative. On the other hand, the neo-Kantian opinion was that the speculative metaphysics should not be replaced by a non-critical confidence in the empirical sciences. Both extremes should be avoided. Here we can return to the beginning of this article, because it was Kant's demand for a critical epistemology that was the crucial point in this way of reasoning (Lübcke 1987:25). This was also emphasised by Auguste Comte, the spiritual father of positivism. Thereby one fundamental principle of evolutionary theory was excluded, namely idealism. This is, however, the only fundamental difference between early and late 19th-century history.

\section{ANGLO-SAXON ANTHROPOLOGY}

This can, I believe, be illustrated by viewing the anthropology of the great E B Tylor. Tylor was highly impressed with Nilsson's evolutionary scheme, his archaeology: "It was with a true appreciation of the bearings of this science that one of its founders, the venerable Professor Sven Nilsson, declared in 1843 in the Introduction to his 'Primitive Inhabitants of Scandinavia', that we are 'unable properly to understand the significance of the antiquities of any individual country without at the same time clearly realizing the idea that they are the fragments of a progressive series of civilization, and that the human race has always been, and still is, steadily advancing in civilization"' (Tylor 1871:55p).

Nilsson's thinking was, at least to some degree, still significant during the 1870 s. The evolutionary aspects are still there. It is also obvious that Tylor thought that the science of history should be in line with natural sci- 
ence. But it was Comte and Mill who influenced Tylor, not Cuvier and Hegel. Tylor wrote: "Comte...scarcely overstated the necessity of this study of development, when he declared at the beginning of his 'Positive Philosophy' that 'no conception can be understood except through its history', and this phrase will bear extension to culture at large" (Tylor 1871: 18). Tylor also maintained that "the phenomena of Culture may be classified and arranged, stage by stage, in a probable order of evolution" (Tylor 1871:5). This meant that a "first step in the study of civilization is to dissect it into details, and to classify these in their proper groups" (Tylor 1871:7). The aim of Anthropology was therefore "to classify such details with a view to marking out their distribution in geography and history, and the relations which exists among them. What the task is like, may be almost perfectly illustrated by comparing these details of culture with the species of plants and animals as studied by naturalists. To the ethnographer, the bow and arrow is a species, the habit of flattening children's skulls is a species, the practice of reckoning numbers by tens is a species. The geographical distribution of these things, and their transmission from region to region, have to be studied as the naturalist studies the geography of his botanical and zoological species" (Tylor 1871:7).

In the Anthropology of Tylor we do not find the religious aspect, or else it does not show as clearly as it does in the thinking of Nilsson, Cuvier and Hegel. The idealistic aspects of early 19 th-century evolutionary theory and the significant religious idea of a plan have been replaced by a diffuse and implicit idea of the logic of evolution. During the end of the 19th century the aim of archaeology, history and anthropology was instead to define more and more rigourous methods and theoretical and empirical arguments in line with the materialistic idea of science. This scientific cul-de-sac was first untied by post-processual archaeology, or more clearly, by post-structural philosophy.
POST-PROCESSUAL ARCHAEOLOGY AND THE RE-INVENTION OF MAN

The functionalist and materialistic thinking, visible in any kind of processual or evolutionary theory, was from the end of the 19th century a part of positivist epistemology. In this context idealism was excluded. Idealism should be understood as an ontology and epistemology contradicting materialistic and realistic ontology and epistemology. This pair of opposites has, as we have seen, deep historical significance. Already during the beginning of the 19th century they were to some extent separated. During the Enlightenment natural science with its rational materialism and empirical mathematical epistemology was of high significance, clearly shown in the pre-archaeological discourse.

One of the great idealists was Hegel. Even in the positivism of Comte we find traces of idealism, but positivist epistemology should be understood as materialism (Eriksson \& Frängsmyr 1993:145pp). The distinction between materialism and idealism has been emphasised by processual archaeology. Processual archaeology is highly materialistic.

It is therefore not surprising that the authors behind Symbolic and Structural Archaeology (Hodder 1982) wanted to re-unite idealism and materialism. The purpose was to place an active individual in the material world and thereby allow the objects to unite with the subjects.

In a way this is a return to early 19thcentury theory. I have pointed out Nilsson's unit of material and immaterial aspects. But post-processual archaeology naturally differs from early 19 th-century theory in many significant ways. During the early 19 th century idealism was synonymous with the plan of God. During the late 20th century idealism is instead a question of the active individual and social aspects. This is also one major difference between processual and post-processual archaeology, and it can be illustrated by Nilsson's critique against materialism. In 
Nilsson's opinion materialism, excluded the God-idea and the synthetic aspects of life. In the post-processual view materialism excludes the living and acting individual and the social and symbolic aspects of life.

Life is therefore in many ways a central theme in idealistic theory. That is why idealism is a good point of departure for an ethical discussion, an ethic that criticises the materialistic and technological view of mankind. But idealism should be turned into an ethic that precedes science. An ethical archaeology can therefore no longer stress that it is a question of science in a materialistic meaning. Materialism was earlier guided or controlled by idealism. Today it should instead be a question of an ethical aspect that precedes and controls the mechanism of a materialistic and technological understanding of mankind. In such a context functional problems will be of subordinate significance but not excluded. Evolutionism in any form should, however, be excluded from archaeology since evolutionary theory is always a question of valuation. Functional and technological aspects have significant meaning, but a society or the human being can never be understood on technological principles. Technology can, on the other hand, be understood on social principles and should above all be subordinated the ethical problems of being. Social principles are therefore to some extent idealistic, but this idealism should be guided by ethical principles. These ethical principles should then precede our social and materialistic views of man and society.

Nilsson maintained that modern natural science and archaeology could not be materialism since the scientist always saw the wisdom of God in the material world. Nilsson's thinking was therefore related to the ethics of Christianity. If this variable is excluded the science of Nilsson would immediately turn into materialism, a technology. The technological aspect would become the guiding principle and the evolution of the spirit, and the immaterial aspects of mankind and the cognitive evolution would thereby be neglected. For both Hegel and Nilsson this would be an absurd way of understanding and viewing mankind. But it is exactly what characterise's processual archaeology, and processual archaeology has accordingly been criticised for its insufficient insight into human actions. Instead human acts have been reduced and subordinated a technological legitimacy. Post-processual archaeology has tried to re-invent or rehabilitate the human by giving the individual (agent) back the initiative. The religious aspects of early 19 th-century archaeology, history and natural science are replaced by a new sublime power, a new metaphysics, a metaphysics that singles out man as a living and thinking being with the power to take command of his own social reality. This gives us a possibility to formulate an ethical archaeology that repudiates the totality of modern thought, that is, the idea that an idealistic and/or materialistic totality is within reach of science.

\section{LÉVINAS}

The difference between the particular and totality in Hegel's theory has been criticised (Taylor 1986:490). One of the more significant critiques was delivered by the FrancoBaltic philosopher Emmanuel Lévinas. The Danish philosopher Peter Kemp has in relation to Lévinas expressed the following statement: "Science is certainly good. But the totality of reason in Western metaphysics is an injustice even when it is used as a historical reflection. In such a situation the existing individual is rooted in a fixed role, in a fixed place and during a fixed time. History can not - even after the death of the individual invalidate the unique existence of the individual. A history writing that does not allow the individual and the particular phenomena to stand out, can only express a political aspect of the individual existence. It can never understand what the 'true' individual is, that is our 'religious being'" (Kemp 1992: 74 , my translation). This religious being is 
the ethics of Lévinas and Kemp.

The plan of God was not within reach of Nilsson. Instead the scientist should describe the visible and sensuous reality - the material world. Lévinas relapsed to this way of reasoning and meant that the Other is not within reach of any form of materialistic thinking. The Other is for Lévinas what God's plan was for Nilsson - a mystery.

The dissociation from the immaterial and idealistic aspects in, for example, processual archaeology and the idea of a totality in both materialistic and idealistic reasoning demand that we return to this discussion. This does not mean that we should return to the pantheistic thinking of Nilsson or try to justify a materialistic understanding of history. Instead it is a question of re-introducing a metaphysics expressed on ethical terms and not on idealistic 19th-century principles. It is with this ethical problem that I would like to end this article.

The philosophy of Lévinas has been viewed as a good alternative to the lack of sensuousness in Heidegger's interpretation of the human existence. Heidegger's philosophy emanated from an ontological point of view. Lévinas has instead the living human body as his point of departure. The aspects of living and life are the foundation for a discussion about the ethical experience and lead to a critique of the principles of totality (Kemp 1992:1 Ipp).

From this point of departure a sphere of familiarity that surrounds the Self plays an important role. This sphere precedes the meeting with the Other: Without this sphere a Self can not exist that can speak about or with the Other. This is crucial if we want to understand how the ethics of Lévinas is related to his apprehension of the human being. The ethics of Lévinas is not only a justification of the Other; but also a justification of subjectivity.

Subjectivity has always been out of reach of the empirical sciences and even more so of biology and sociology. In biology man has been examined as a material body and in sociology as a species or a social being. Science has therefore understood the human being as something outside of itself (Kemp 1992: $23 \mathrm{pp}$ ). The order of totality, which neglects the particular and individual and creates supraindividual structures of meaning, is questioned. If we here return to Cuvier's and Nilsson's synthetic view of life and the materialistic aspects of life, Lévinas' critique will be clear.

Two aspects of knowledge are thereby identified. The first has to do with empirical reality. This reality is, however, always something else than the ideas we have about it. It exists beyond our power of imagination. This should not be confused with pragmatism or fictionism. Instead this should be the case if we want to separate the Self from the Other: Such knowledge will always be separated from a way of reasoning that seeks the similar.

The second form of knowledge is categorisation. In this case the Other is joined with our way of reasoning and reality will remain the same - the Other is turned into the Same. Nothing is allowed to disturb the freedom of the autonomous thought, the original production of knowledge. By criticising this second form of knowledge, Lévinas points out the tendency in philosophy and science to make the unfamiliar familiar and reduce the Other to the Same. By this kind of reduction it is believed that an understanding has been established, synonymous with truth and the triumph of the autonomous thought. However, knowledge can in this case only be part of a monologue. It has nothing to do with a dialogue. It also demands universal validity and that everything that is thought to exist within the totality is embraced. Yet the Other is neglected or absorbed by the Same, and we find in this kind of science and philosophy an "ego-ology", a narcissism, in which thoughts only meet with their own mirror-reflected image (Kemp 1992:34).

Even an object is understood as a neutral 
grandeur and not as an isolated case. This kind of generalisation dissolves the alterity (the otherness), a way of reasoning not only criticised by Lévinas but also by Foucault (1993) and Geertz (1973) and by post-processual archaeology (Hodder 1982a:4, 1987:2; Tilley 1982:32pp; Shanks \& Tilley 1987:57). Generalisations are not innocent abstractions. On the contrary. They can result in domination and repression by the tendency to force the particular to become something else. This is clear if we use the human subject as an example (Kemp 1992:35), or the Other in history.

Generalisations might even give unobstructed space for the desire for power. The aim of Lévinas is therefore to find ways to express the experience of something external, the otherness, without turning this into the Same (Kemp 1992:37). Thereby he is presenting an alternative to the principle of totality, a way of reasoning distinguished by the belief that a totality will be embraced when all the aspects thought to be essential are included.

Lévinas does not try to overcome differences by a synthesis that unites the Other with the Same. Instead he respects the Other in its otherness. This should be the case because the Self is an independent subject with the right to retain its originality. The Other is therefore always something new. A meeting with the Other can thus never be foreseen or imagined but only established face to face (Kemp 1992:39p). We should in this way avoid joining together ourselves and the Other by conception. On the other hand we can always talk. This means that the relationship between ourselves and the Other takes shape in language.

Language implies a speaking partner. The conversation emanates on such terms from the presence of the Other: It is in this relationship that the significance of language takes shape and not by classification, generalisation, monologue or consensus. This also means that neither the speaker nor the ad- dressed can be placed in a category. The scientific demands of accessibility presuppose for that reason an inter-subjectivity. This demand is based on an ethical principle, which is not an addition to knowledge but its foundation. Every form of reasoning and knowledge presupposes thus the Other (Kemp 1992:48pp).

It is in the conversation - this meeting that the ethical aspect appears and one's being is problemised by the presence of the Other: In ontology this being is only defined and identified. The alienation of the Other should therefore not be reduced to the same as oneself, should not be a part of one's own possessions and thoughts. This is, however, the result of modern epistemology. Through ethics this reduction is problemised. If we, on the other hand, consider ontology (the doctrine of being, or the doctrine of reality) as the fundamental doctrine there is a risk that we will produce an unjust philosophy (science) that might lead to totalitarianism - the worst consequence of the principle of totality.

Since the 19th century differences have been arranged hierarchically. The Other has been categorised in accordance with scientific reasoning and objectivity. Through, for example, generalisations the Other is turned into the Same and the specific characteristics of the Other are invalidated. To establish this order of science the discourses have been standardised and the differences abolished. We have therefore through the history of archaeology tried to obtain consensus and a homogeneous understanding on two levels: in relation to the Other in history, and in relation to our colleagues. In my opinion this can only be viewed as totalitarianism, that is, opposite of what was thought to be obtained by the demands for objectivity and tools of measurement.

But an ontology that does not depend on ethics is in many ways impossible. This is so because the relationship to the Other should be the fundamental principle for any under- 
standing of being, i.e. ontology. This means that ontology presupposes ethics. Because the contrary is not the case, ethics is the first philosophy (Kemp 1992:42). Lévinas therefore criticises any ontology that reduces the Other to the Same. He criticises any ethic or other kind of scientific reasoning that tries to obtain a universal generality. He regards this way of reasoning as a way of controlling the Other (Kemp 1992:66).

The plurality in Lévinas' point of departure is not only a question of different existences, different because of heredity and environment. The plurality is instead a question of someone standing before one, face to face with one. There is therefore no totality, for example in a Hegelian way of reasoning, no society as a super-organism and no historical evolution as a gigantic process in the thoughts of Lévinas (Kemp 1990:189). Kemp and Lévinas have, through their understanding of the ethical relationship, indirectly contributed to a criticism of modern archaeology and its goal to obtain a totality. This in turn helps us to widen the scope of postprocessual criticism.

For Lévinas, ethics is the first philosophy and the analysis of the face is used as a philosophical argument when the ethical experience is elucidated. But Lévinas also uses this argument to criticise Hegel's idea of a totality and Heidegger's neutral apprehension of being (Kemp 1992:22).

Lévinas tries to find a way out of the Western philosophy of totality, a philosophy that has, in Lévinas' opinion, conquered or even forgotten the detail, the individual, the Other: The philosophy of Lévinas expresses a criticism that is not captured by arguments for a totality. Subjectivity has earlier been understood as a negation of totality. This way of reasoning made it possible for Hegel and others to neutralize the particular, that is, that the particular is always dependent on the totality because the particular must take shape as a negation of totality. Even if we tried to think in an opposite way, that is allow the particular to neutralize totality, we would still find ourselves captured by the problem of negation. It has therefore been difficult to criticise Hegel without at the same time being caught by his way of reasoning and placed in his system of totality and negation (Kemp 1992:31).

\section{A COMMENT}

Archaeology has since the early 19 th century been a part of the conception of modern man. Modern archaeology is therefore a tautology, that is, an continuing repetition of this conception. By a basic critique of the complicated modern aspects of reasoning, light has been thrown on this narcissism. Post-processual archaeology has contributed to this critique. This archaeology has unmasked a totalitarianism that has promoted the real or imagined Western domination over other prehistoric or contemporary - social constellations.

Lévinas has formulated one of the most important critiques against the modern tradition of thought. The ethics of Lévinas has helped us to understand that the Other should be the point of departure when we express an opinion, even if it is a question of people no longer alive. This also means that we should meet the Other "face to face" before we comment on his or her being, i.e. ontology. The Other should be given the right to respond, that is, a dialogue with the Other should be created. If the Other is neglected or reduced to part of a system, structures or evolution, and at the same time we place ourselves outside, there is a risk that we will create an unjust relationship to the Other: A more justified relationship might be expressed by the question, "How do you understand your being?" a question that contradicts the statement, "This is how you should understand your being!" The step from such a statement to the totalitarian predication "This is how your being must be", is not far away.

English revised by Laura Wrang. 


\section{REFERENCES}

Binford, L. 1968. Archeological Perspectives. In: Binford, S \& Binford, L. (Eds.). New Perspectives in Archeology. Chicago.

Eriksson, G. \& Frängsmyr, T. 1993. Idéhistoriens huvudlinjer. Stockholm.

Foucault, M. 1991. The order of things. An archaeology of the human sciences. London.

- 1992. Upplysningen, revolutionen och framstegets möjlighet. In: Östling, B. (Ed.). Vad är upplysning? Kant, Foucault, Habermas, Mendelssohn, Heidegger. Stockholm/Stehag.

- 1993. Diskursens ordning. Stockholm/Stehag.

Frängsmyr, F. 1976. Upptäckten av istiden. Studier i den moderna geologins framväxt. Stockholm.

Geertz, C. 1973. Thick Description: Toward an Interpretive Theory of Culture. In: The Interpretation of Cultures. BasicBooks.

Hegel, F. 1986. Förnuftet i historien. Göteborg.

Hodder I. 1982. (Ed.). Symbolic and structural archaeology. Cambridge.

- 1982a. Theoretical archaeology: a reactionary view. In: Hodder, I. (Ed.). Symbolic and Structural Archaeology. Cambridge.

- 1987. The contextual analysis of symbolic meanings. In: Hodder, I. (Ed.). The archaeology of contextual meanings. Cambridge University Press.

Kemp, P. 1990. Döden och maskinen. En introduktion till Jaques Derrida. Stockholm/Stehag.

- 1992. Emmanuel Lévinas. En introduktion. Göteborg.

Lübcke, P. 1987. Filosofins förfall. In: Lübcke, P. (Ed.). Vår tids filosofi. Stockholm.

Löwgren, Y. 1983. Sven Nilsson, zoologen. In: Regnéll, G. (Ed.). Sven Nilsson. En lärd $i$ I800-talets Lund. Lund.

Nilsson, S. 1835. Skandinavisk fauna. Foglarna. Ny omarbetad upplaga. Bd. 1-2. Lund.

- 1838-43. Skandinaviska Nordens Ur-invånare, ett försök i den komparativa ethnografien och ett bidrag till menniskoslägtets utvecklingshistoria. Första delen. Lund.

- 1843. Bidrag till menniskoslägtets utvecklingshistoria. Forhandlingar vid de skandinaviske naturforskarnes 3:de möte, i Stockholm den 13-19 juli 1841. Stockholm.
- 1848. Bidrag til kunskapen om menniskans tillvaro och verksamher i Skandinavien under den första tiden. Aftryck fra" Forhandlinger ved de skandinaviske Naturforskeres fjerde Möde i Christiania, den 11-18 Juli 1844. Christiania.

- 1856. Ethnografiska anteckningar: Vetenskapsakademiens öfversigt af Kungliga Vetenskapsakademiens Forhandlingar 4. Stockholm.

- 1866. Skandinaviska Nordens Ur-invånare, ett försök i den komparativa ethnografien och ett bidrag tillmenniskoslägtets utvecklingshistoria. Första delen. Lund.

- 1875a. Inträdes-föreläsning den 10 December 1832, vid förf:s installation som professor $\mathrm{i}$ zoologi vid Universitetet i Lund. In: Samlade smärre skrifter af Professor Sven Nilsson. Häfte I. Stockholm.

- 1875b. Promotorsprogram, hvarigenom inbjudning utfärdades till filosofiska fakulteternas promotionsfest i Lund den 23:dje Juni 1853. In: Samlade smärre skrifter af Professor Sven Nilsson. Häfte I. Stockholm.

- 1875c. Föredrag vid Skandinaviska naturforskaremötet i Stockholm 1842. Med några ändringar och tillägg. Bidrag till menniskoslägtets utvecklingshistoria. In: Samlade smärre skrifter af Professor Sven Nilsson. Häfte 1. Stockholm.

Regnéll, G. 1983a. Zoologen och arkeologen som var geolog. In: Regnéll, G. (Ed.) Sven Nilsson. En lärd i 1800-talets Lund. Lund.

- 1983b. Av stubbotan rot. In: Regnéll, G. (Ed.). Sven Nilsson. En lärd i 1800 -talets Lund. Lund.

Shanks, M. \& Tilley, C. 1987. Social theory and archaeology. Cambridge.

Taylor, C. 1986. Hegel. Stockholm/Lund.

Tilley, C. 1982. Social formation, social structures and social change. In: Hodder, I. (Ed.). Symbolic and structural archaeology. Cambridge.

- 1989. Interpreting material culture. In: Hodder, I. (Ed.). The Meanings of Things. Material Culture and Symbolic Expression. London.

Tylor, E. B. 1871. Primitive Culture. Researches into the development of mythology, philosophy, religion, language, art, and custom Vol. I - II. London. 
